\title{
Pengaruh Terapi Bermain (Berdongeng) Terhadap Perkembangan Bahasa Pada Anak Usia Prasekolah (3 - <6 Tahun) Di PAUD Ukuwah Islamiah Desa Penujak Kecamatan Praya Barat Kabupaten Lombok Tengah
}

\author{
Husnul $^{1)}$, Muhamad Sunarto ${ }^{2)}$, Edy Surya Pratama $^{2)}$, Lalu Azhari ${ }^{3)}$ \\ Email: edysurya31@gmail.com \\ 1) Mahasiswa S1 Keperawatan UNIQHBA \\ 2) Dosen Prodi S1 Keperawatan UNIQHBA \\ 3) Universitas Qamarul Huda Badaruddin
}

\begin{abstract}
ABSTRAK
Bahasa adalah suatu system komunikasi yang digunakan secara sukarela dan secara sosial disetujui bersama, dengan menggunakan simbol-simbol tertentu untuk menyampaikan dan menerima pesan dari satu orang ke orang lain. Salah satu keterlambatan yang bisa terjadi pada anak adalah keterlambatan perkembangan bahasa. Salah satu stimulus yang dapat diberikan orang tua untuk meningkatkan perkembangan bahasa anak adalah dengan berdongeng. Tujuan penelitian ini adalah untuk mengetahui pengaruh terapi bermain (berdongeng) terhadap perkembangan bahasa pada anak usia prasekolah (3-<6 tahun). Desain penelitian ini adalah penelitian eksperimen pre test dan post test dengan pendekatan penelitian kuantitatif. Penelitian ini melibatkan dua kelompok yaitu kelompok eksperimen dan kelompok kontrol. Sampelnya adalah semua anak usia prasekolah yang terdaftar di PAUD Ukuwah Islamiah Desa Penujak yang mengalami gangguan bahasa. Teknik pengambilan sampel dalam penelitian ini adalah total sampling dengan jumlah 40 responden. Hasil uji statistik berdasarkan tabel 4.11 didapatkan nilai $\mathrm{t} 2.137$ dengan $\mathrm{t}$ tabel sebesar 1.684 dan nilai $\mathrm{p}=0.039$ yang artinya nilai $\mathrm{t}>$ nilai $\mathrm{t}$ tabel atau nilai $\mathrm{p}<\alpha$ sehingga dapat disimpulkan adanya perubahan secara signifikan perkembangan bahasa pada anak usia prasekolah setelah diberikan terapi bermain (berdongeng).
\end{abstract}

Kata kunci : perkembangan bahasa, terapi mendongeng

\begin{abstract}
Language is a communication system that is used voluntarily and socially agreed upon, by using certain symbols to convey and receive messages from one person to another. One delay that can occur in children is the delay in language development. One stimulus that parents can give to improve children's language development is by telling stories. The purpose of this study was to determine the effect of play therapy (storytelling) on language development in preschool children (3- <6 years). The design of this study is an experimental research pre test and post test with a quantitative research approach. This study involved two groups, namely the experimental group and the control group. the sample was all preschool children enrolled in PAUD Ukuwah Islamiah Penujak Village who had language problems. The sampling technique in this study was total sampling with 40 respondents. The results of statistical tests based obtained $t$ value of 2.137 with $t$ table of 1.684 and $p$ value $=0.039$ which means the value of $t>t$ table value or $p$ value $<\alpha$ so it can be concluded that there is a significant change in language development in preschool children after playing therapy (storytelling).
\end{abstract}

Keywords: language development, storytelling therapy 


\section{A. LATAR BELAKANG}

Bahasa adalah suatu system komunikasi yang digunakan secara sukarela dan secara sosial disetujui bersama, dengan menggunakan simbol-simbol tertentu untuk menyampaikan dan menerima pesan dari satu orang ke orang lain. Termasuk didalamnya adalah tulisan, bicara, bahasa simbol, ekspresi muka, isyarat, pantomim dan seni. Menurut teori neuropsikolinguistik, berbahasa adalah interaksi yang kompleks antara fungsi otak (kortek serebri), semantik, fragmantik, fonologi, grammar dan organ yang memproduksi bahasa [1].

Populasi anak-anak di dunia saat ini berjumlah 1,9 miliar anak yaitu 27\% dari populasi penduduk dunia. Menurut proyeksi Badan Pusat Statistik (BPS) tahun 2017, jumlah penduduk Indonesia tahun 2017 ini mencapai 261 juta jiwa yang terdiri dari 129,9 juta laki-laki dan 128,7 juta perempuan. Jumlah anak di bawah 18 tahun sekitar 91,8 juta jiwa atau sekitar 35\%, sedangkan jumlah anak usia 0-4 tahun tercatat sebanyak 19,1 juta jiwa (data Kementrian Kesehatan Republik Indonesia, 2017). Berdasarkan Badan Pusat Statistik (2017) jumlah anak usia 0-9 tahun Kabupaten Lombok Tengah sekitar 184. 454 jiwa[2].

Berdasarkan survey pendahuluan yang dilakukan di PAUD Ukuwah Islamiah pada tanggal 12 februari 2018, jumlah anak yang berusia $3->6$ tahun berjumlah 40 anak yang terbagi menjadi 2 kelas yakni kelas A dan B, dengan guru pengajar terdiri dari 3 orang. Dari hasil wawancara dengan 3 orang siswa yang diambil secara acak didapatkan 2 orang siswa tidak dapat menjawab pertanyaan peneliti secara spontan dan 1 orang tidak menjawab pertanyaan peneliti dan hanya berdiam diri. Dan wawancara yang dilakukan terhadap 3 orang tua, ketiga orang tua mengatakan tidak pernah mendongeng kepada anaknya dan tidak mengetahui manfaat dari mendongeng dapat memperluas kosakata anak serta dapat mengembangkan kemampuan bahasa anak dan tujuannya untuk mendeteksi dini ganggguan perkembangan bahasa pada anak.

Salah satu stimulus yang dapat diberikan orang tua untuk meningkatkan perkembangan bahasa anak adalah dengan berdongeng. Adapun tujuan dari mendongeng atau story telling adalah menuangkan gagasan dalam pikiran tidak saja untuk menghibur pendengarnya, namun juga untuk menularkan nilai-nilai yang terkandung dalam inti cerita. Dongeng bermanfaat dapat memperkaya perbendaharaan kata anak. Ditambah lagi dengan mendengarkan dongeng akan melatih daya tangkap anak selama proses menyimak. Tentu saja latihan konsentrasi ini akan melatih ingatan anak untuk berpikir lebih detail mengenai suatu obyek dan memperbanyak kosakata anak, suatu modal yang sangat diperlukan bagi pengembangan kemampuan komunikasi verbal[3].

Berdasarkan penjelasan di atas yang menyebutkan bahwa mendengarkan dongeng dapat meningkatkan kemampuan bahasa anak dengan aspek peningkatan bahasa, yaitu bertambahnya perbendaharaan kata yang dimiliki anak. Hal inilah yang menjadi alasan dasar peneliti tertarik untuk meneliti tentang "Pengaruh terapi bermain (berdongeng) terhadap perkembangan bahasa pada anak usia prasekolah (3 - <6 tahun) di PAUD Ukuwah Islamiah Desa Penujak Kecamatan Praya Barat Kabupaten Lombok Tengah Tahun 2018".

\section{B. METODE PENELITIAN}

\section{Desain Penelitian}

Desain penelitian adalah suatu rancangan yang bisa dipergunakan oleh peneliti sebagai petunjuk dalam merencanakan dan melaksanakan penelitian untuk mencapai tujuan atau jawaban pertanyaan penelitian[4]. Desain penelitian ini adalah penelitian eksperimen dengan pendekatan penelitian kuantitatif.

\section{Populasi}

Adalah keseluruhan subyek penelitian [4]. Dalam penelitian ini yang menjadi populasi adalah anak usia prasekolah di PAUD Ukuwah Islamiah Desa Penujak yang berjumlah 40 anak 
prasekolah.

\section{Sampel}

Sampel adalah sebagian atau wakil populasi yang diteliti[5]. Dalam penelitian ini yang menjadi sampelnya adalah semua anak usia prasekolah yang terdaftar di PAUD Ukuwah Islamiah Desa Penujak.

\section{Teknik sampling}

Teknik sampling adalah suatu cara yang ditempuh dengan pengambilan sampel yang benar-benar sesuai dengan keseluruhan obyek penelitian[6]. Teknik pengambilan sampel dalam penelitian ini adalah total sampling.

\section{HASIL DAN PEMBAHASAN}

1. Hasil

a. Perkembangan Bahasa Anak Usia Prasekolah (3-<6 Tahun) Sebelum (Pretest) terapi bermain (berdongeng) pada kelompok eksperimen

Tabel.1 Perkembangan Bahasa Anak Usia Prasekolah (3-<6 Tahun) Sebelum (Pre-test) terapi bermain (berdongeng) pada kelompok eksperimen

\begin{tabular}{|c|c|c|}
\hline Perkembangan & \multicolumn{2}{|c|}{ Kelompok Eksperimen } \\
\hline Bahasa & Frekuensi & $\%$ \\
\hline Suspect & 13 & 65 \\
\hline Normal & 7 & 35 \\
\hline Total & 20 & 100 \\
\hline
\end{tabular}

Perkembangan bahasa anak usia prasekolah sebelum diberikan perlakuan terapi bermain (berdongeng) pada kelompok eksperiment yaitu sebagian besar perkembangan bahasa suspect 13 responden $(65 \%)$ dan perkembangan bahasa normal 7 responden (35\%)

\section{b. Perkembangan Bahasa Anak Usia Prasekolah (3-<6 Tahun) Sebelum (Pre- test) pada kelompok kontrol \\ Perkembangan bahasa anak usia prasekolah} (3-<6 tahun) sebelum (pre-test) pada kelompok kontrol tanpa diberikan perlakuan terapi bermain (berdongeng) pada kelompok perlakuan sebagian besar perkembangan bahasanya suspect yakni sebanyak 14 responden (70\%) dan perkembangan bahasa normal sebanyak 6 responden $(30 \%)$.
Tabel.2 Perkembangan Bahasa Anak Usia Prasekolah (3-<6 Tahun) Sebelum (Pre-test) terapi bermain (berdongeng) pada kelompok kontrol

\begin{tabular}{|c|c|c|}
\hline Perkembangan & \multicolumn{2}{|c|}{ Kelompok control } \\
\hline Bahasa & Frekuensi & $\%$ \\
\hline Suspect & 14 & 70.0 \\
\hline Normal & 6 & 30.0 \\
\hline Total & 20 & 100.0 \\
\hline
\end{tabular}

c. Perkembangan Bahasa Anak Usia Prasekolah (3-<6 Tahun) (Pos-test) terapi bermain (berdongeng) pada kelompok Perlakuan

Tabel.3 Perkembangan Bahasa Anak Usia Prasekolah (3-<6 Tahun) (Pos-test) terapi bermain (berdongeng) pada kelompok Perlakuan

\begin{tabular}{|c|c|c|}
\hline Perkembangan & \multicolumn{2}{|c|}{ Kelompok Eksperimen } \\
\hline Bahasa & Frekuensi & $\%$ \\
\hline Suspect & 3 & 15 \\
\hline Normal & 17 & 85 \\
\hline Total & 20 & 100 \\
\hline
\end{tabular}

Perkembangan bahasa anak usia prasekolah (3-<6 tahun) setelah diberikan perlakuan terapi bermain (berdongeng) pada kelompok eksperimen sebagian besar perkembangan bahasa adalah normal yakni sebanyak 17 responden $(85 \%)$ dan perkembangan bahasa normal sebanyak 3 responden (15\%).

d. Perkembangan Bahasa Anak Usia Prasekolah (3-<6 Tahun) sesudah (Posttest) terapi bermain (berdongeng) pada kelompok control

Tabel.3 Perkembangan Bahasa Anak Usia Prasekolah (3-<6 Tahun) sesudah (Post-test) terapi bermain (berdongeng) pada kelompok control

\begin{tabular}{|c|c|c|}
\hline Perkembangan & \multicolumn{2}{|c|}{ Kelompok kontrol } \\
\hline Bahasa & Frekuensi & $\%$ \\
\hline Suspect & 12 & 60 \\
\hline Normal & 8 & 40 \\
\hline Total & 20 & 100 \\
\hline
\end{tabular}

Perkembangan bahasa anak usia prasekolah (3-<6 tahun) pada kelompok kontrol sebagian besar perkembangan bahasa adalah suspect yakni sebanyak 12 responden (60\%) dan perkembangan bahasa normal sebanyak 3 responden $(40 \%)$, 
e. Analisa Pengaruh Terapi Bermain (berdongeng) terhadap Perkembangan Bahasa Anak Usia Prasekolah (3-<6 Tahun) di PAUD Ukuwah Ilamiah Desa Penujak Kecamatan Praya Barat Kabupeten Lombok Tengah

Perkembangan bahasa anak usia prasekolah (3-<6 tahun) pada kelompok eksperimen sebelum diberikan perlakuan sebagian besar perkembangan bahasanya dalam kategori suspect yakni sebanyak 13 (65\%) responden, sedangkan setelah diberikan perlakuan terapi bermain (berdongeng) sebagian bersar perkembangan bahasanya normal yakni sebanyak 17 responden (85\%). Perkembangan bahasa pada kelompok kontrol tidak mengalami perubahaan pada saat pertama kali dilakukan pengunkuran dan pengulangan pengukuran yakni sebagian besar suspect.

\section{Pembahasan}

a. Perkembangan Bahasa Anak Usia Prasekolah (3-<6 Tahun) Sebelum (Pretest) diberikan Perlakuan Terapi Bermain (Berdongeng) pada Kelompok Eksperimen dan Kelompok Kontrol tanpa Perlakuan di PAUD Ukuwah Ilamiah Desa Penujak Kecamatan Praya Barat Kabupeten Lombok Tengah

Sebelum melakukan penelitian, peneliti memberikan pre-test pada kelompok eksperimen maupun kelompok kontrol. Pre-test tersebut bertujuan untuk mengetahui kemampuan awal kedua kelompok berbeda jauh atau tidak. Hasil pre-test menunjukkan nilai rata-rata yang hampir sama, yaitu kelompok eksperimen sebesar 3.20, sedangkan kelompok kontrol memiliki nilai ratarata sebesar 3.75. Peneliti mengambil kesimpulan bahwa kemampuan yang dimiliki siswa kelompok eksperimen dengan kelompok kontrol sebelum mendapatkan perlakuan adalah sama.

perkembangan bahasa anak usia prasekolah sebelum diberikan perlakuan terapi bermain (berdongeng) yaitu didapatkan data perkembangan bahasa dari 40 responden sebagian besar suspect yakni sebanyak 13 responden (65\%) pada kelompok eksperimen dan 14 responden (70\%) pada kelompok kontrol.

Menurut Baverly Otto menyatakan bahwa perbedaan perkembangan bahasa yang dimiliki anak disebabkan oleh pemahaman anak yang berbeda-beda sesuai dengan usia anak, kadar emosional anak, dan pengalaman yang dimiliki oleh setiap anak[7].

Menurut asumsi peneliti hal ini terjadi dikarenakan belum adanya kegiatan bermain atau pelajaran yang diterapkan di PAUD tersebut yang bertujuan untuk meningkatkan perkembangan bahasa anak usia prasekolah. Salah satu kegiatan yang dapat meningkatkan kemampuan berbahasa anak adalah mendongeng, karena dengan mendongeng dapat menambah kosakata, meningkatkan imajinasi dan kreativitas anak selain itu juga dapat melatih konsentrasi anak. Hal ini didukung dengan penelitian yang dilakukan oleh Septyani (2014) yang menyatakan bahwa adanya perubahan perkembangan bahasa secara signifikan terhadap anak usia 3-5 tahun setelah diberikan cerita bergambar sebanyak 6 kali.

Menurut Hurlock Salah satu faktor yang mempengaruhi perkembangan bahasa adalah dorongan atau stimulus. Semakin banyak dorongan untuk belajar berbicara dengan mengajak anak berbicara maka semakin awal anak belajar berbicara sehingga semakin pula baik kualitas berbicara anak. Orang tua terutama ibu merupakan guru pertama bagi anak untuk mengembangkan kemampuan berbicara anak. Pendapat ini didukung oleh Soetjiningsih menyatakan bahwa anak yang mendapatkan stimulasi (dorongan) yang teratur dan terarah maka perkembangan bahasanya akan lebih baik dari pada anak yang kurang atau tidak mendapatkan stimulasi (dorongan)[1].

Menurut asumsi peneliti ada beberapa faktor yang mempengaruhi perkembangan bahasa anak usia prasekolah.. Responden yang perkembangan bahasanya masuk dalam kategori suspect sebagian besar berjenis kelamin laki laki. Jenis kelamin dapat mempengaruhi perkembangan bahasa hal ini dikarenakan anak 
laki - laki cenderung lebih suka permainan aktif yang tidak terlalu membutuhkan banyak percakapan, hal ini berbeda dengan anak perempuan yang lebih suka permainan pasif seperti bermain boneka, mendengarkan dongeng, bermain peran. Permainan tersebut membutuhkan banyak percakapan sehingga dapat dapat memperbanyak kosakata yang dimili. Selain jenis terdapat faktor lain yang mempengaruhi perkembangan bahasa anak usia prasekolah yaitu usia anak, pengalaman pribadi anak dan motivasi keluarga.

b. Perkembangan Bahasa Anak Usia Prasekolah (3-<6 Tahun) Setelah (Posttest) diberikan Perlakuan Terapi Bermain (Berdongeng) pada Kelompok Eksperimen dan Kelompok Kontrol tanpa Perlakuan di PAUD Ukuwah Ilamiah Desa Penujak Kecamatan Praya Barat Kabupeten Lombok Tengah

Kelompok eksperimen setelah diberikan perlakuan terapi bermain (berdongeng) selama 10 kali perlakuan perkembangan bahasanya mengalami peningkatan yakni terdapat 10 responden $(50 \%)$ mengalami perubahan perkembangan bahasa dari suspect menjadi normal.

Hasil penelitian yang dilakukan Daroah (2013) metode bercerita dengan bantuan media audio visual maka perkembangan bahasa kelompok B1 RA terdapat peningkatan kemampuan bahasa sebelumdiberikan perlakuan $50 \%$ menjadi $84 \%$ dari 32 anak.

Menurut asumsi peneliti, perkembangan bahasa dan kemampuan berbicara pada anak usia dini sangat penting karena dengan bahasa sebagai dasar kemampuan, seorang anak akan dapat meningkatkan kemampuan yang lain. Menerapkan ide-ide untuk mengembangkan kemampuan berbahasa dan berbicara anak, memberikan contoh penggunaan bahasa dengan benar, dan menstimulasi perkembangan bahasa anak dengan berkomunikasi secara aktif. Anak perlu terus dilatih untuk berpikir dan menyelesaikan masalah melalui bahasa dan bicara yang dimilikinya. Kegiatan nyata yang diperkuat dengan komunikasi akan terus meningkatkan kemampuan bahasa dan berbicara anak. Salah satu kegiatan tersebut adalah berdongeng atau bercerita. Metode bercerita dapat memberikan dampak positif bagi prestasi dan hasil belajar anak.

Kelompok kontrol setelah dilakukan penilaian ulang perkembangan bahasanya mengalami peningkatan tetapi tidak terlalu besar yakni hanya 2 responden (10\%) mengalami perubahan perkembangan bahasa dari suspect menjadi normal.

Soetjiningsih menyatakan bahwa anak yang mendapatkan stimulasi (dorongan) yang teratur dan terarah maka perkembangan bahasanya akan lebih baik dari pada anak yang kurang atau tidak mendapatkan stimulasi (dorongan)[1].

Menurut asumsi peneliti, dari hasil penelitian pada kelompok kontrol jumlah responden sebagian besar berjenis kelamin laki-laki yakni sebanyak 11 responden (55\%). Salah satu faktor yang mempengaruhi perkembangan bahasa selain adanya stimulus atau dorongan adalah jenis kelamin, dimana anak laki- laki pada usia prasekolah lebih rentan mengalami keterlambatan bahasa dan berbicara.

Selain perbedaan peningkatan perkembangan bahasa, terdapat perbedaan mean pada masing - masing kelompok yakni kelompok eksperimen sebesar 4.70 dan kelompok kontrol sebesar 4.05. Sehingga dapat disimpulkan bahwa kondisi akhir kelompok eksperimen dan kelompok kontrol menunjukkan perbedaan. Dan kelompok eksperimen memiliki perkembangan bahasa lebih baik dari pada kelompok kontrol.

\section{c. Analisa Pengaruh Terapi Bermain (berdongeng) terhadap Perkembangan Bahasa Anak Usia Prasekolah (3-<6 Tahun) di PAUD Ukuwah Ilamiah Desa Penujak Kecamatan Praya Barat Kabupeten Lombok Tengah}

Kelompok eksperimen didapatkan adanya perubahan perkembangan bahasa dari $35 \%$ menjadi $85 \%$ berarti terdapat peningkatan sebesar 50\%. Pada kelompok control terdapat 
perubahan perkembangan bahasa dari $30 \%$ menjadi $40 \%$ ini artinya ada peningkatan tetapi tidak signifikan yakni hanya $10 \%$. Selain itu, terdapat peningkatan nilai mean pada kelompok eksperimen nilai mean pre-test 3.20 menjadi 4.70 berarti terdapat peningkatan yang cukup signifikan yakni sebesar 1.5, sedangkan pada kelompok kontrol nilai mean pre-test 3.75 menjadi 4.05 sehingga peningkatannya tidak begitu besar yakni hanya sebesar 0.3.

Hasil uji statistik berdasarkan tabel 4.11 didapatkan nilai t 2.137 dengan $t$ tabel sebesar 1.684 dan nilai $\mathrm{p}=0.039$ yang artinya nilai $\mathrm{t}>$ nilai $\mathrm{t}$ tabel atau nilai $\mathrm{p}<\alpha$ sehingga dapat disimpulkan adanya perubahan secara signifikan perkembangan bahasa pada anak usia prasekolah setelah diberikan terapi bermain (berdongeng). Kesimpulan akhir dari data - data diatas adalah adanya Pengaruh terapi bermain (berdongeng) terhadap perkembangan bahasa anak usia prasekolah (3-<6 tahun) di PAUD Ukuwah Islamiah Desa Penujak yang dibuktikan dengan hasil uji $\mathrm{t}$-test diperoleh nilai $\mathrm{t}>\mathrm{t}$ tabel yakni $2.137>1.684$ atau nilai $\mathrm{p}<\alpha$ yakni $0.000<0.05$ maka Ho ditolak dan Ha diterima.

Penelitian serupa oleh Lola Wita Harahap terhadap 15 responden didapatkan hasil adanya peningkatan perkembangan bahasa dan berbicara melalui metode bercerita dengan menggunakan boneka tangan[8].

Perkembangan bahasa dan kemampuan berbicara pada anak usia dini sangat penting karena bahasa merupakan dasar kemampuan, seorang anak akan dapat meningkatkan kemampuan yang lain. Pendidik perlu memberikan stimulus yang tepat untuk meningkatkan perkembangan berbahasa dan berbicara anak, memberikan contoh penggunaan bahasa yang benar, dan menstimulasi perkembangan bahasa anak dengan menberikan dongeng yang menarik serta berkomunikasi secara aktif. Anak perlu terus dilatih untuk berpikir, mengembangkan imajinasi mereka dan menyelesaikan masalah melalui kemampuan bahasa dan bicara yang dimilikinya. Kegiatan nyata yang diperkuat dengan komunikasi akan terus meningkatkan perkembangan bahasa dan berbicara anak. Lebih daripada itu, anak harus ditempatkan diposisi yang terutama, sebagai pusat pembelajaran yang perlu dikembangkan potensinya.

Menurut asumsi peneliti dilihat dari faktor faktor yang mempengaruhi perkembangan bahasa anak pemberian stimulus atau dorongan adalah salah satu faktor yang memiliki peluang besar untuk dapat dirubah. Dalam hal ini peneliti memberikan stimulus berupa terapi bermain (berdongeng) dimana anak diajak untuk belajar sambil bermain. Kegiatan berdongeng atau bercerita merupakan suatu kegiatan yang ampuh dalam menyalurkan ide atau gagasan kepada anak. Merangkai kata-kata persuasif, deskriptif, naratif atau imajinatif menjadi satu kisah yang atraktif, sekedar untuk berbagi makna cerita. Berdongeng terhadap anak akan melatih daya tangkap anak selama proses mendengarkan dongeng. Latihan konsentrasi ini akan melatih daya ingat anak untuk berfikir secara lebih detail tentang obyek yang diceritakan. Manfaat lain berdongeng dapat menambah jumlah kosakata yang dimiliki anak sehingga dapat meningkatkan kemampuan komunikasi verbal anak, dapat juga mengembangkan daya imajinasi anak dan kreatifitas anak. Kata-kata yang menarik dan penuh makna dalam dongeng dapat mendorong anak untuk menciptakan gambar-gambar yang jelas dalam pikiran anak. Tentu saja, ini akan memupuk kretifitas dalam diri anak dan dapat meningkatkan kemampuan visual anak.

\section{KESIMPULAN}

Perkembangan bahasa pada anak usia prasekolah (3-<6 tahun) di PAUD Ukuwah Islamiah desa Penujak pada kelompok eksperimen setelah diberikan perlakuan terapi bermain (berdongeng) terdapat peningkatan menjadi normal, sedangkan pada kelompok kontrol tanpa perlakuan perkembangan bahasanya tidak ada peningkatan yakni sebagian besar suspect (meragukan). 


\section{E. UCAPAN TERIMAKASIH}

Tim peneliti mengucapkan terimakasih kepada segenap pihak yang telah terlibat di dalam penelitian ini. termasuk kerabat rekan dan instansi dari PAUD dan anak-anak yang telah menjadi responden.

\section{DAFTAR PUSTAKA}

[1] Soetjiningsih. 2016. Tumbuh Kembang Anak Edisi II. Jakarta : EGC

[2] Supratna, Lalu. Statistik Daerah Kabupaten Lombok Tengah 2017. https://lomboktengahkab.bps.go.id. Diakses pada tanggal 19 April 2018 pukul 1730.

[3] Mustofa, Bisri. 2015. Melejitkan Kecerdasan Anak Melalui Dongeng. Yogyakarta : Parama Ilmu.
[4] Suharsimi, Arikunto. 2017. Prosedur Penelitian Suatu Pendekatan Praktik. Jakarta : Rineka Cipta.

[5] Notoatmodjo.2012. Metodologi Penelitian Kesehatan.Jakarta: Rineka Cipta

[6] Suwarjana, I Ketut. 2015. Metodologi Penelitian Kesehatan, Edisi Revisi. Yogyakarta:Andi Offset.

[7] Otto, Baverly. 2015. Perkembangan Bahasa Pada Anak Usia Dini. Jakarta : Kencana.

[8] Harahap, Wita Lola. 2017. Meningkatkan Perkembangan Bahasa dan Kemampuan berbicara melalui Metode Bercerita Dengan Menggunakan Boneka Tangan. (Online http://semnasfis.unimed.ac.id . pdf, diakses 3 Maret 2018) 